\title{
PENGARUH PERENCANAAN PAJAK DAN INSENTIF NON PAJAK TERHADAP MANAJEMEN LABA PADA PERUSAHAAN MANUFAKTUR YANG TERDAFTAR DI BURSA EFEK INDONESIA TAHUN 2013-2017
}

\author{
Mohamad Sutrisno, Yanti Puji Astuti \\ Program Studi Akuntansi \\ Fakultas Ekonomi dan Bisnis Universitas Pancasakti
}

\begin{abstract}
The Effect of Tax Planning and Non-Tax Incentives toward Earnings Management at Manufacturing Companies listed on Indonesia Stock Exchange 2013-2017. Thesis, Tegal: Faculty of Economics, Pancasakti University Tegal. 2018. The purpose of this study is to examine the effect of tax planning and non-tax incentives simultaneously and partially toward earnings management at manufacturing companies listed on the Indonesia Stock Exchange in 2013-2017. This research is descriptive research with quantitative approach. The sample used is automotive sub-sector manufacturing companies and components listed in Indonesia Stock Exchange period 2013-2017. The number of companies sampled this research there are 45 companies by using purposive sampling method. While the data analysis method used is descriptive statistical test, classical assumption test, multiple linear regression analysis, simultaneous significance test ( $F$ test), test of individual parameter significance ( $T$ test) and coefficient of determination. Based on the results of research indicate that tax planning and non-tax incentive simultaneously have a significant effect toward earnings management with significance value 0,000. While partially tax planning, earnings pressure and firm size have significant effect to earnings management with value of significance respectively 0,037,0,000 and 0,049. As well as leverage and earnings bath partially no effect toward earnings management with a significance value of 0.436 and 0.146 respectively.
\end{abstract}

Keywords : Tax planning, earnings pressure, leverage, earnings bath, company size, earnings management

\section{PENDAHULUAN}

Laporan keuangan merupakan salah satu alat penting sebagai bahan pertimbangan untuk pengambilan keputusan dalam ekonomi perusahaan. Laporan keuangan memuat informasiinformasi penting yang dibutuhhkan oleh para penggunanya., seperti stakeholder dan manajer perusahaan itu sendiri. Dalam pengelolaanya, perusahaan memperhatikan setiap poin yang dianggap penting karena mempengaruhi kinerja manajemen. Salah satunya adalah pembebanan pajak penghasilan atas laba yang diperoleh (Hamijaya, 2015:2).

Salah satu dari tujuan yang ingin dicapai manajemen adalah mendapatkan laba yang tinggi, hal ini berkaitan juga dengan bonus yang akan diperoleh oleh manajemen, karena semakin tinggi laba yang diperoleh maka akan semakin tinggi pula bonus yang akan diberikan oleh perusahaan kepada manajemen yang merupakan pihak pengelola secara langsung. Di lain pihak, informasi laba dapat membantu pemilik (stakeholder) dan investor dalam mengestimasi 
kekuatan laba (earnings power) untuk memprakirakan resiko dalam investasi dan kredit. Pentingnya informasi laba tersebut merupakan tanggungjawab dari pihak manajemen yang diukur kinerjanya dari pencapaian laba yang diperoleh. Situasi ini memungkinkan manajer untuk melakukan perilaku menyimpang dalam menyajikan dan membuat laporan informasi laba tersebut yang dikenal dengan praktik manajemen laba (earnings management) (Astutik dan Mildawati, 2016:1).

Sulistyanto (2014:51) menyatakan manajemen laba (earnings management) merupakan aktivitas manajerial untuk 'mempengaruhi' dan 'mengintervensi' laporan keuangan, dengan melakukan upaya merekayasa angka-angka dalam laporan keuangan dengan mempermainkan metode dan prosedur akuntansi yang digunakan perusahaan. Sedangkan menurut Harnanto (2013:115) upaya untuk merekayasa informasi melalui manajemen laba telah menjadi faktor utama yang menyebabkan laporan keuangan tidak lagi mencerminkan nilai fundamental suatu perusahaan. Oleh karena itu, isu ini bisa saja merugikan pihak-pihak yang berkepentingan dalam hal ini pihak yang memakai informasi laporan keuangan, karena tidak menggambarkan bagaimana kondisi perusahaan yang sebenarnya. Kondisi ini disebut sebagai asimetri informasi (information asymetric), yaitu kondisi dimana ada ketidakselarasan perolehan informasi antara pihak manajemen sebagai penyedia informasi dengan pemegang saham dan stakeholder.

Manajemen mempunyai wewenang dan keleluasaan dalam memaksimalkan laba perusahaan. Hal ini mengarah pada proses memaksimalkan kepentingan pribadi dengan biaya yang harus ditanggung oleh pemilik perusahaan.
Upaya ini untuk meningkatkan nilai perusahaan tidak lagi mencerminkan kinerja yang sesungguhnya, namun telah direkayasa sedemikian rupa sehingga menjadi lebih baik sesuai dengan keinginan. Akan tetapi stakeholder mempunyai hak untuk memperoleh semua informasi secara akurat dan tepat waktu. Dalam artian semua pemegang saham tanpa terkecuali mempunyai hak yang sama untuk memperoleh informasi yang sama (transparancy) (Sulistyanto, 2014:132-134)

Praktik manajemen semacam ini banyak sekali dilakukan dalam perusahaan besar, dengan tujuan menarik para pelaku pasar untuk berinvestasi dalam perusahaan. Tentu praktik manajemen seperti ini akan mempengaruhi eksistensi perusahaan karena laporan yang disajikan hanya bersifat semu serta akan merugikan pihak perusahaan dan emiten. Hal yang lebih baik apabila yang dipublikasikan oleh perusahaan sesuai apa yang terjadi atau minimal mendekati kondisi sesungguhnya perusahaan tersebut, baik untuk laporan pajak ataupun laporan kepada investor (Astutik dan Mildawati, 2016:2).

Dalam pembangunan suatu negara Infrastruktur merupakan kebutuhan dasar fisik yang diperlukan untuk jaminan ekonomi sektor publik dan sektor privat sebagai layanan dan fasilitas perekonomian. Kebijakan Pemerintahan saat ini menjadikan pembangunan infrastruktur sebagai prioritas utama program pembangunan nasional. Seperti, pembangunan jalan tol serta jalan antar kota dan antar provinsi. Pembangunan infrastruktur yang dilakukan pemerintah akan berdampak pada meningkatnya perekonomian. Hal ini akan dimanfaatkan perusahaan otomotif untuk terus meningkatkan produksi. Karena akan mempermudah pendistribusian 
produk ke berbagai pelosok negeri. Manajemen akan menyadari, hal ini juga akan membuat konsumen merasa lebih nyaman sehingga dapat meningkatkan penjualan produk dan berpotensi meningkatkan laba perusahaan.

Selain fenomena tersebut, perusahaan otomotif juga akan melakukan hal lain yang berpeluang meningkatkan laba atau mempertahankan laba perusahaan. Scott (2003) dalam Astutik dan Mildawati (2016) mengemukakan bahwa salah satu jenis manajemen laba adalah dengan melakukan income smoothing, yaitu manajemen dapat menaikan atau menurunkan laba untuk mengurangi fluktuasi laba sehingga perusahaan terlihat stabil dan tidak beresiko tinggi. Berdasarkan laporan keuangan yang diterbitkan Astra International (ASII) tahun 2015 memperoleh laba Rp

15.613.000.000.000, tahun $2016 \mathrm{Rp}$ 18.302.000.000, dan $2017 \quad \mathrm{Rp}$ 23.165.000.000.000. Hal ini mengindikasikan bahwa Astra International (ASII) melakukan manajemen laba dengan cara income smoothing.

Pajak merupakan kewajiban yang pengenaan atau pemungutannya didasarkan pada peraturan perundangundangan dan bukan iuran/pungutan bersifat suka rela, jadi pajak tidak perlu dibayar lebih dari jumlah yang seharusnya dibayar. Secara sengaja tidak melaporkan adanya suatu penghasilan, aktivitas, transaksi atau perbuatanperbuatan yang berakibat timbulnya kewajiban pajak, dengan maksud mengurangi jumlah pajak yang terutang atau penggelapan pajak merupakan tindakan ilegal (tax evasion) sehingga berpotensi akan mempunyai konsekuensi sanksi administrasi berupa denda, bunga bahkan pidana (Harnanto, 2013:3).
Astutik dan Mildawati (2016:2) menyatakan laba perusahaan yang tinggi akan menyebabkan beban pajak perusahaan tinggi pula. Oleh sebab itu, manajemen melakukan perencanaan pajak yang agresif melalui pelaporan laba perusahaan. Dengan tujuan mencapai target laba perusahaan, manajemen akan melakukan berbagai tindakan untuk merekayasa angka laba dalam laporan keuangan. Berbagai tindakan yang dilakukan manajemen perusahaan menunjukan bahwa perencanaan pajak dilakukan untuk memanipulasi aktivitas perusahaan untuk menggelapkan pajak (real earnings management).

Perencanaan pajak (tax planning) merupakan salah satu fungsi dari manajemen pajak yang digunakan untuk mengestimasi jumlah pajak yang akan dibayar dan hal-hal yang dilakukan untuk menhindari pajak. Dalam penelitian ini salah satu isu yang digunakan adalah motif penghindaran pajak yang tidak sesuai dengan peraturan perpajakan. Dengan didasari terungkapnya kasus penggelapan pajak yang dilakukan beberapa perusahaan di Indonesia dengan cara melakukan pembiayaan fiktif, ekspor fiktif dan transfer pricing untuk merekayasa hasil penjualan (Astutik dan Mildawati, 2016:2). Selain perencanaan pajak yang terindikasi mempengaruhi manajemen laba, insentif non pajak juga dapat mempengaruhi manajemen laba. Hal ini sesuai dengan penelitian yang dilakukan Hamijaya (2015:5) yang menyatakan Insentif non pajak merupakan insentif yang diberikan oleh perusahaan dengan tujuan untuk memaksimalkan dan mempertahanka produktifitas karyawan yang memiliki prestasi agar terus bekerja diperusahaan tersebut.

Berdasarkan latar belakang yang sudah diuraikan diatas, maka rumusan 
masalah dalam penelitian ini adalah : 1) Apakah perencanaan pajak dan insentif non pajak berpengaruh terhadap manajemen laba pada perusahaan manufaktur yang terdaftar di Bursa Efek Indonesia tahun 2013-2017? 2) Apakah perencanaan pajak berpengaruh terhadap manajemen laba pada perusahaan manufaktur yang terdaftar di Bursa Efek Indonesia tahun 2013-2017? 3) Apakah insentif non pajak berpengaruh terhadap manajemen laba pada perusahaan manufaktur yang terdaftar di Bursa Efek Indonesia tahun 2013-2017?

Tujuan penelitian ini adalah : 1) Untuk mengetahui pengaruh perencanaan pajak dan insentif non pajak terhadap manajemen laba pada perusahaan manufaktur yang bergerak dibidang otomotif dan komponen yang terdaftar di BEI tahun 2013-2017; 2) Untuk mengetahui pengaruh perencanaan pajak terhadap manajemen laba pada perusahaan manufaktur yang bergerak dibidang otomotif dan komponen yang terdaftar di BEI tahun 2013-2017; 3) Untuk mengetahui pengaruh insentif non pajak terhadap manajemen laba pada perusahaan manufaktur yang bergerak dibidang otomotif dan komponen yang terdaftar di BEI tahun 2013-2017.

\section{KERANGKA PEMIKIRAN DAN HIPOTESIS}

Kerangka pemikiran adalah pondasi dimana seluruh proyek penelitian didasarkan, kerangka pemikiran yaitu jaringan asosiasi yang disusun, dijelaskan, dan dielaborasi secara logis antarvariabel yang dianggap relevan pada situasi masalah dan diidentifikasi melalui proses seperti pengamatan, survey, literatur, dan wawancara (Sekaran, 2006:127).
Pengaruh Perencanaan Pajak dan Insentif Non Pajak Terhadap Manajemen Laba

Perencanaan pajak (tax planning) merupakan salah satu fungsi dari manajemen pajak yang digunakan untuk mengestimasi jumlah pajak yang akan dibayar dan hal-hal yang dilakukan untuk menhindari pajak. Dalam penelitian ini salah satu isu yang digunakan adalah motif penghindaran pajak yang tidak sesuai dengan peraturan perpajakan. Dengan didasari terungkapnya kasus penggelapan pajak yang dilakukan beberapa perusahaan di Indonesia dengan cara melakukan pembiayaan fiktif, ekspor fiktif dan transfer pricing untuk merekayasa hasil penjualan (Astutik dan Mildawati, 2016:2). Selain perencanaan pajak yang terindikasi mempengaruhi manajemen laba, insentif non pajak juga dapat mempengaruhi manajemen laba. Hal ini sesuai dengan penelitian yang dilakukan Hamijaya (2015:5) yang menyatakan Insentif non pajak merupakan insentif yang diberikan oleh perusahaan dengan tujuan untuk memaksimalkan dan mempertahanka produktifitas karyawan yang memiliki prestasi agar terus bekerja diperusahaan tersebut. Dengan demikian, terdapat hubungan yang positif antara perencanaan pajak dan insentif non pajak dengan manajemen laba.

H1. Perencanaan pajak dan insentif non pajak berpengaruh terhadap manajemen laba

Pengaruh Perencanaan Pajak Terhadap Manajemen Laba

Perencanaan pajak (tax planning) merupakan salah satu fungsi dari manajemen pajak yang digunakan untuk mengestimasi jumlah pajak yang akan dibayar dan hal-hal yang dapat dilakukan untuk menghindari pajak. Perencanaan pajak terkait dengan pelaporan laba 
perusahaan. Laba yang tinggi akan menyebabkan beban pajak perusahaan juga tinggi. Perencanaan pajak dan manajemen laba terkait satu sama lain, karena sama-sama bertujuan untuk mencapai target laba dengan merekayasa angka laba dalam laporan keuangan (Astutik, 2015, 2016:2).

Perencanaan pajak terkait dengan pelaporan laba perusahaan. Laba yang tinggi akan menyebabkan beban pajak perusahaan juga tinggi. Oleh karena itu, manajemen perusahaan akan menggunakan berbagai teknik manajemen laba untuk mencapai target. Perencanaan pajak dan manajemen laba terkait satu sama lain, karena sama-sama bertujuan untuk mencapai target laba dengan merekayasa angka laba dalam laporan keuangan. Berbagai tindakan yang dilakukan oleh perusahaan untuk menggelapkan pajak menunjukkan bahwa perencanaan pajak dilakukan dengan memanipulasi aktivitas operasi perusahaan (real earnings management).

H2. Perencanaan Pajak berpengaruh terhadap manajemen laba

Pengaruh Insentif Non Pajak

Tehadap Manajemen Laba

Insentif non pajak merupakan insentif yang diberikan oleh perusahaan dengan tujuan untuk memaksimalkan dan mempertahanka produktifitas karyawan yang memiliki prestasi agar terus bekerja diperusahaan tersebut. Hal ini menjadi salah satu pengaruh perusahaan untuk melakukan manajemen laba. Berdasarkan penelitian Yin dan Cheng (2004) dalam Hamijaya (2015:5), insentif non pajak yang dapat digunakan adalah sebagai berikut :

\section{Pengaruh Earnings Pressure Terhadap Manajemen Laba}

Penurunan laba yang dilakukan oleh manajer karena laba perusahaan telah mencapai terget merupakan upaya dalam menghadapi earning pressure. Subagyo (2010:7) menyatakan insentif pajak mengimplikasikan bahwa perusahaan akan memilih untuk menurunkan laba sebagai respon atas penurunan laba. Untuk perusahaan yang labanya tidak mencapai target, penurunan laba yang dilakukan untuk tujuan pajak dapat dikurangi oleh earnings pressure guna meningkatkan laba akuntansi. Hal ini dilakukan untuk menaikan laba akuntansi guna meningkatkan nilai perusahaan.

H3a. Earnings pressure berpengaruh terhadap manajemen laba

\section{Pengaruh Tingkat Hutang}

Terhadap Manajemen Laba

Leverage menggambarkan hubungan antara hutang perusahaan terhadap modal dan asset perusahaan. Tingkat leverage yang tinggi menggambarkan semakin tingginya risiko perusahaan tidak dapat melunasi hutangnya. Sebaliknya, tingkat leverage yang rendah menunjukan bahwa perusahaan lebih banyak membiayai asetnya dengan modal sendiri (Yenisa, 2017).

Sulistyanto (2014:45-46) menyatakan Debt (Equity) Hypothesis menyatakan dalam konteks perjanjian hutang manajer akan mengelola dan mengatur labanya agar kewajiban hutangnya yang seharusnya diselesaikan pada tahun tertentu dapat ditunda untuk tahun berikutnya. Hipotesis ini berkaitan dengan syarat-syarat yang harus dipenuhi perusahaan didalam perjanjian utang (debt convenant). Sebagian perjanjian utang mempunyai syaratsyarat yang harus dipenuhi peminjam selama masa perjanjian. Jika perusahaan mulai mendekati suatu pelanggaran terhadap perjanjian utang, maka perusahaan tersebut akan menghindari terjadinya utang dengan cara memilih 
metode akuntansi yang meningkatkan laba. Pelanggaran terhadap perjanjian utang dapat menimbulkan suatu biaya serta dapat menghambat kinerja manajemen. Sehingga dengan meningkatkan laba perusahaan berusaha untuk mencegah atau setidaknya menunda hal tersebut.

H3b. Tingkat hutang berpengaruh terhadap manajemen laba

\section{Pengaruh Earnings Bath Terhadap Manajemen Laba}

Earning bath dilakukan dengan dengan menggeser laba periode yang memiliki laba tinggi ke periode yang labanya lebih rendah guna meningkatkan laba. Apabila pada periode berjalan memiliki laba yang rendah maka perusahaan cenderung menggeser laba periode mendatang ke periode berjalan untuk meningkatkan laba periode berjalan yang rendah dan sebaliknya apabila laba periode berjalan tinggi perusahaan cenderung menggeser laba periode berjalan ke periode mendatang untuk menjaga agar laba tahun mendatang dapat mencapai target yang diharapkan.

H3c. Earnings bath berpengaruh terhadap manajemen laba

\section{Pengaruh Ukuran Perusahaan \\ Terhadap Manajemen Laba}

Secara umum, ukuran dapat diartikan sebagai suatu perbandingan besar atau kecilnya objek. Jika pengertian ini dihubungkan dengan perusahaan atau organisasi, maka ukuran perusahaan dapat diartikan sebagai suatu perbandingan besar atau kecilnya usaha dari suatu perusahaan. Ukuran perusahaan juga dapat menggambarkan besar kecilnya suatu perusahaan yang dapat dinyatakan dengan total aset ataupun total penjualan bersih. Semakin besar total aset maupun penjualan maka semakin besar pula ukuran suatu perusahaan. Semakin besar aset maka semakin besar pula modal yang ditanam, sementara semakin banyak penjualan maka semakin banyak juga perputaran uang dalam perusahaan (Hery, 2017:1112).

H3d. Ukuran perusahaan berpengaruh terhadap manajemen laba

\section{METODE PENELITIAN}

\section{Populasi dan Sampel}

Populasi dalam penelitian ini adalah perusahaan yang terdaftar di Bursa Efek Indonesia. Pengambilan sampel dalam penelitian ini meliputi perusahaanperusahaan manufaktur di sub sektor otomotif dan komponen yang terdaftar di Bursa Efek Indonesia (go public) tahun 2013-2017. Pengambilan sampel ini dilakukan dengan pertimbangan jumlah perusahaan manufaktur yang banyak. Sedangkan teknik yang digunakan dalam penelitian ini menggunakan cara purposive sampling dimana sampel yang dipilih berdasarkan pertimbangan atau kriteria-kriteria tertentu penelitian yang dilaksanakan.

\section{Variabel dan Definisi Operasional Variabel}

\section{Variabel}

Variabel yang terdapat pada penelitian ini adalah variabel terikat (dependent variable) dan variabel bebas (independent variable). Variabel terikat adalah variabel yang menjadi perhatian utama peneliti dengan tujuan untuk mengetahui variabel-variabel bebas yang mempengaruhinya dan menemukan jawaban atau solusi atas suatu masalah. Variabel bebas adalah variabel yang mempengaruhi variabel terikat, baik secara positif ataupun negatif (Sekaran, 2011:116-118). Variabel yang digunakan dalam penelitian ini terdiri atas enam variabel yaitu variabel terikat 
manajemen laba serta variabel bebas perencanaan pajak, earnings pressure, tingkat hutang, earnings bath dan ukuran perusahaan.

\section{Definisi Operasional Variabel dan Pengukuran}

\section{Manajemen Laba}

Rosensweig dan Fischer (1994) dalam Sulistiyanto (2014:49) menyatakan, manajemen laba adalah tindakan manajer untuk menaikan atau menurunkan laba berjalan dari sebuah perusahaan yang dikelolanya tanpa menyebabkan kenaikan (penurunan) keuntungan ekonomi perusahaan jangka panjang. Manajemen laba dalam penelitian ini menggunakan pendekatan distribusi laba (earnings thresholds). Sesuai dengan penelitian Philips et al (2003) dalam Astutik dan Mildawati (2016) apabila nilai distribusi laba nol atau positif, maka perusahaan menghindari penurunan laba. Dan bila nilai distribusi laba negatif, maka perusahaan menghindari pelaporan keuangan. Philips et al (2003) mengukur manajemen laba dengan rumus:

$$
\Delta E=\frac{E_{i t}-E_{i t-1}}{M V E_{i t-1}}
$$

Keterangan:

$$
\begin{aligned}
\Delta E= & \text { Distribusi laba, dimana bila } \\
& \Delta E \text { adalah nol atau positif, } \\
& \text { maka perusahaan } \\
& \text { menghindari penurunan } \\
& \text { menghindari laba. Bila nilai } \\
& \Delta E \text { adalah negatif, maka } \\
& \text { perusahaan menghindari } \\
& \text { laporan kerugian } \\
= & \text { Laba perusahaan i pada } \\
& \text { tahun } \mathrm{t} \\
E_{i t}= & \text { Laba perusahaan i pada } \\
& \text { tahun } \mathrm{t}-1 \\
E_{i t-1}= & \text { Market Value of Equility } \\
& \text { perusahaan i pada tahun } \mathrm{t}-1 .
\end{aligned}
$$
$E_{i t} \quad=$ Laba perusahaan i pada tahun $\mathrm{t}$

Dalam penelitian ini, peneliti menggunakan tingkat kapalitasasi sebagai proksi Market Value of Equility . Nilai kapitalisasi tersebut diukur dengan mengalikan jumlah saham beredar perusahaan i pada akhir tahun t-1 dengan harga perusahaan i pada akhir tahun $\mathrm{t}-1$

\section{Perencanaan Pajak}

Perencanaan pajak (tax planning) merupakan salah satu fungsi dari manajemen pajak yang digunakan untuk mengestimasi jumlah pajak yang akan dibayar dan hal-hal yang dapat dilakukan untuk menghindari pajak. Perencanaan pajak terkait dengan pelaporan laba perusahaan. Laba yang tinggi akan menyebabkan beban pajak perusahaan juga tinggi. Perencanaan pajak dan manajemen laba terkait satu sama lain, karena sama-sama bertujuan untuk mencapai target laba dengan merekayasa angka laba dalam laporan keuangan (Astutik dan Mildawati :2016). Perencanaan pajak dalam penelitian ini diukur dengan menggunakan Tax Retention Rate (TRR), rumus yang digunakan (Wild et al :2004) :

$$
T R R_{i t}=\frac{\text { Net Income }}{\text { Pretax Income }\left(E B I T_{i t}\right)}
$$

Keterangan:

$T R R_{i t}+$ Tax retention Rate perusahaan $\mathrm{i}$ pada tahun $\mathrm{t}$

Net Income $=$ Laba bersih perusahaan i pada tahun $\mathrm{t}$

$E B I T_{i t}=$ Laba sebelum pajak perusahaan i pada tahun $\mathrm{t}$

\section{Earnings Pressure \\ Hamijaya (2015) menyatakan earnings pressure merupakan upaya yang dilakukan perusahaan untuk}


menurunkan laba, sehingga pajak yang akan dibayar menjadi lebih kecil. Subagyo (2010), Ristyanti dan Syarifudin (2012), Slamet dan awijayanti (2012), Widyawanti (2014) dan Hamijaya (2015) mengukur earnings pressure dengan laba tahun berjalan dikurangi laba tahun sebelum kemudian dibagi total aset awal tahun. Rumus :

$$
\text { EPress }_{i t}=\frac{N_{i t}-N_{i t-1}}{T A_{0}}
$$

Keterangan :

Epressit $=$ Earnings pressure

Nit $=$ Laba tahun berjalan

Nit-1 = Laba tahun lalu

TA0 = Total aset awal tahun

\subsection{Tingkat Hutang}

Leverage rasio dapat dikatakan sebagai cerminan dari struktur modal perusahaan (Sulistyo, 2010). Leverage rasio ini digunakan untuk mengukur tingkat aktivitas perusahaan yang dibiayai oleh hutang. Hamijaya (2015) menyatakan tingkat hutang merupakan rasio yang digunakan untuk mengukur leverage perusahaan. Suzuki dan Okabe (1999) dalam Hamijaya (2015) mengukur tingkat hutang pada penelitian ini diukur dengan membagi hutang dengan ekuitas.

$$
\text { Rumus : } \mathrm{LEV}=\frac{\text { Debt }}{\text { Equity }}
$$

Keterangan :

$L E V=$ Leverage

Debt $=$ Total hutang

Equity $=$ Total ekuitas

\section{Earnings Bath}

Widyawanti (2014) menyatakan earnings bath merupakan peristiwa yang ditandai dengan menurunnya laba perusahaan. Earnings bath dalam pemelitian ini diproksikan dengan peringkat ROE perusahaan, sehingga manajer akan memperkecil total akrual agar dapat memperoleh kompensasi di masa mendatang. Earning Bath diukur dengan menggunakan rumus (Subagyo, 2010; Ristyanti dan Syarifudin, 2012; Slamet dan awijayanti, 2012; Widyawanti, 2014 serta Hamijaya, 2015)

$\mathrm{ROE}=\frac{\text { Laba bersih }}{\text { Ekuitas }} \times 100 \%$

Keterangan :

ROE = Return On Equity

Laba bersih = Laba bersih tahun berjalan

Ekuitas $\quad=$ Total ekuitas

Ukuran Perusahaan

Ukuran perusahaan adalah suatu nilai yang mencerminkan besar atau kecilnya ukuran perusahaan (Hamijaya :2015). Subagyo (2010), Ristyanti dan Syarifudin (2012), Slamet dan Wijayanti (2012), Widyawanti (2014) serta Hamijaya (2015) mengukur perusahaan dalam penelitian ini menggunakan $\log n$ (logaritma natural) dikalikan nilai total aset serta rumus yang digunakan :

$$
\text { Size }=\log n(\text { Total aset })
$$

Keterangan :

Size $=$ Ukuran perusahaan

Logn $=$ Logaritma natural

\section{Teknik Analisis Data}

\section{Uji Asumsi Klasik}

Untuk menguji hipotesis penelitian ini dengan menggunakan regresi linier berganda. Sebagai prasyarat regresi linier berganda dilakukan uji asumsi klasik untuk memastikan bahwa data penelitian valid, tidak bias, konsisten, dan penaksiran koefisien regresinya bersifat efisien. Pengujian asumsi klasik meliputi uji normalitas, uji 
multikolinearitas, uji autokorelasi, dan uji heteroskedastisitas.

\section{Metode Penelitian}

Model yang digunakan adalah Analisis regresi linier berganda, untuk menguji pengaruh antara variabel bebas dengan variabel terikat.

Lebih lanjut dengan model persamaan sebagai berikut:

$$
\begin{aligned}
& Y=\alpha+\beta 1 X 1+\beta 2 a X 2 a+\beta 2 b X 2 b+ \\
& \beta 2 c X 2 c+\beta 2 d X 2 d+\varepsilon
\end{aligned}
$$

Keterangan :

$\mathrm{Y}=$ Manajemen Laba

$\mathrm{X} 1=$ Perencanaan pajak

$\mathrm{X} 2=$ Insentif non pajak

$\mathrm{X} 2 \mathrm{a}=$ Earning Pressure

$\mathrm{X} 2 \mathrm{~b}=$ Leverage

$\mathrm{X} 2 \mathrm{c}=$ Earning Bath

$\mathrm{X} 2 \mathrm{~d}=$ Ukuran Perusahaan

$$
\begin{array}{ll}
A & =\text { Konstanta } \\
\beta 1-5 & =\text { Koefisien regresi } \\
\varepsilon & =\text { Tingkat kesalahan (error) }
\end{array}
$$

\section{HASIL PENELITIAN}

\section{Statistik Deskriptif}

Statistik deskriptif memberikan deskripsi (gambaran) suatu data yang dilihat dari nilai minimum, maksimum, rata-rata (mean), dan standar deviasi yang dihasilkan dari variabel penelitian. (Ghozali, 2016:19). Sebelum melakukan analisis data, maka terlebih dahulu ditinjau mengenai desktiptif variabel penelitian dengan statistik deskriptif. Statistik deskriptif memberikan gambaran atau deskripsi suatu data yang dapat dilihat dari nilai rata-rata (mean), standar deviasi, maksimum, dan minimum. Hasil uji statistik deskriptif adalah sebagai berikut:

Tabel 4.1.

Hasil Uji Statistik Deskriptif

Descriptive Statistics
\begin{tabular}{|l|l|l|l|l|l|}
\hline & N & Minimum & Maximum & Mean & Std. Deviation \\
Manajemen Laba & 45 &,- 5966 & 2,2323 & 036076 & 3930082 \\
Perencanaan Pajak & 45 & $-1,3226$ & 32,0413 & 2,199274 & 5,4021968 \\
Earnings Pressure & 45 &,- 1290 &, 9554 &, 015166 &, 1502086 \\
Leverage & 45 &, 1351 & 8,2613 & 1,261514 & 1,3316187 \\
Earnings Bath & 45 & $-1,2578$ &, 8263 &, 106030 &, 2761585 \\
Ukuran Perusahaan & 45 & 25,9468 & 33,3202 & 29,362308 & 1,9647572 \\
Valid N (listwise) & 45 & & & & \\
\hline
\end{tabular}

Sumber: Output SPSS, data yang diolah (2018)

Berdasarkan tabel 4.3 di atas, dapat diketahui bahwa data obesrvasi penelitiian ini sebanyak 45 perusahaan. Berikut ini keterangan dari data analisis statistik deskriptif yang telah diolah adalah sebagai berikut :

Variabel Manajemen Laba (Y) memiliki nilai rata-rata sebesar 0,036076, nilai maksimum sebesar 2,2323, nilai minimum sebesar -0,5966, dan standar deviasi sebesar 0,3930082.
VariabelPerencanaanPajak(X1) memiliki nilai rata-rata sebesar 2,199274, nilai maksimum sebesar 32,0413, niliai minimum sebesar -1,3226, dan standar deviasi 5,4021968.

Variabel Earnings Pressure (X2a) memiliki nilai rata-rata sebesar $\quad 0,015166, \quad$ nilai maksimum sebesar 0,9554 , niliai minimum sebesar 0,1290, dan standar deviasi 0,1502086. 
Variabel Leverage (X2b) memiliki nilai rata-rata sebesar 1,261514, nilai maksimum sebesar 8,2613 , niliai minimum sebesar 0,1351 , dan standar deviasi 1,3316187.

Variabel Earnings Bath (X2c) memiliki nilai rata-rata sebesar 0,106030, nilai maksimum sebesar 0,8263, niliai minimum sebesar -1,2578, dan standar deviasi 0,2761585.

Variabel Ukuran Perusahaan (X2d) memiliki nilai rata-rata sebesar 29,362308, nilai maksimum sebesar 33,3202, niliai minimum sebesar 25,9468, dan standar deviasi 1,9647572 .

\section{Uji Asumsi Klasik}

\section{Uji Normalitas}

Uji normalitas bertujuan untuk menguji apakah model regresi, variabel dependen dan variabel independen, keduanya mempuyai distribusi normal atau tidak. Uji normalitas menggunakan Kolmogorov-Smirnov. Model regresi yang baik adalah yang memiliki distribusi data normal atau mendekati normal (Ghozali, 2016:154). Hasil dan Uji Normalitas adalah :

\section{Tabel 4.2}

\section{Hasil Uji Kolmogorof-Smirnov}

One-Sample Kolmogorov-Smirnov Test

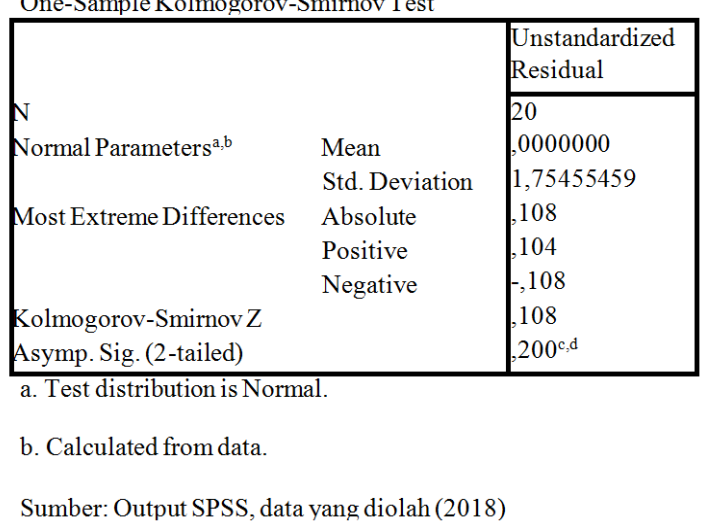

Berdasarkan pada tabel 4.5 besarnya nilai uji Kolmogorov- smirnov (K-S) adalah 0,108 dan nilai Asymp. Sig. (2-tailed) sebesar 0,200 lebih besar dari 0,05. Hal ini menunjukan data residual sudah terdistribusi secara normal dan model regresi layak dipakai untuk penelitian.

\section{Uji Multikolonieritas}

Uji multikolonieritas bertujuan untuk menguji apakah pada model regresi ditemukan adanya kolerasi antara variabel bebas (independent). Metode yang digunakan untuk mendeteksi adanya multikolonieritas adalah dengan menggunakan nilai Tolerance dan Variance Inflation Factor (VIF) (Ghozali, 2016:103). Dengan menggunakan nilai tolerance, nilai yang terbentuk harus diatas $10 \%$, sedangkan dengan menggunakan VIF nilai yang terbentuk kurang dari 10, bila tidak maka akan terjadi multikolinearitas dan model regresi tidak dapat digunakan.

Berdasarkan hasil perhitungan data SPSS didapat hasil sebagai berikut:

Tabel 4.3

Uji Multikolonieritas

\begin{tabular}{|ll|ll|}
\hline \multicolumn{3}{|l|}{} & \multicolumn{2}{|l|}{ Collinearity Statistics } \\
Model & Tolerance & VIF \\
1 & (Constant) & & \\
& LAGX1 & & \\
& LAGX2a \\
LAGX2b & 855 & 1,169 \\
LAGX2c & 496 & 2,015 \\
LAGX2d & 784 & 1,276 \\
& 522 & 1,914 \\
& & 591 & 1,693
\end{tabular}

Melihat keterangan diatas, dapat disimpulkan bahwa tidak ada variabel independen yang mempunyai nilai tolerance kurang dari $10 \%$ dan juga menunjukkan hal yang sama dimana tidak ada satupun variabel 
independen memiliki nilai VIF lebih dari 10, hal ini menunjukkan tidak adanya korelasi antar variabel independen dan dapat digunakan model regresi dalam penelitian.

\section{Uji Autokorelasi}

Pengujian autokolerasi dilakukan dengan metode Durbin Watson (DW-

\section{Tabel 4.4.}

Hasil Uji Autokorelasi

\begin{tabular}{l|r|r|r|r|r|}
\hline Model & \multicolumn{1}{|c|}{ Model Summary } \\
\hline 1 &, $612^{\mathrm{a}}$ & R Square & $\begin{array}{c}\text { Adjusted R } \\
\text { Square }\end{array}$ & $\begin{array}{c}\text { Std. Error of the } \\
\text { Estimate }\end{array}$ & Durbin-Watson \\
\hline
\end{tabular}
a. Predictors: (Constant), LAGX2D, LAGX2B, LAGX1, LAGX2A, LAGX2C
b. Dependent Variable: LNY

Sumber: Output SPSS, data yang diolah (2018)

Berdasarkan tabel 4.4, hasil pengujian setelah dilakukan transformasi diperoleh nilai DurbinWatson sebesar 2,056. Nilai tersebut, kemudian dilakukan pengambilan keputusan dengan ketentuan du $<\mathrm{d}<$ 4 -du $(1,7762<2,056<2,2238)$. Hal ini dapat disimpulkan bahwa tidak terjadi autokorelasi antara variabel independen dan penelitian dapat dilanjutkan dengan menggunakan model regresi.

\section{Uji Heterokedastisitas}

Model regresi yang baik adalah model regresi yang memenuhi syarat heteroskedastisitas dan dalam penelitian metode yang digunakan untuk menguji menggunakan grafik scatterplot dan analisisnya adalah sebagai berikut :

Jika ada pola tertentu seperti titik - titik yang membentuk pola tertentu yang teratur (bergelombang, melebar atau penyempit) maka dapat diindikasikan telah terjadi heteroskedastisitas.
Test). Uji autokorelasi dalam penelitian ini dideteksi dengan melihat nilai Durbin Watson dalam Autokortealbaesli pengambilan keputusan (Ghozali, 2016:107). Hasil uji autokorelasi dalam penelitian ini dapat dilihat pada tabel berikut :
Jika ada pola yang tidak teratur seperti titik - titik yang menyebar diatas dan dibawah angka nol pada sumbu Y, maka dapat diindikasikan tidak terjadi heteroskedastisitas.

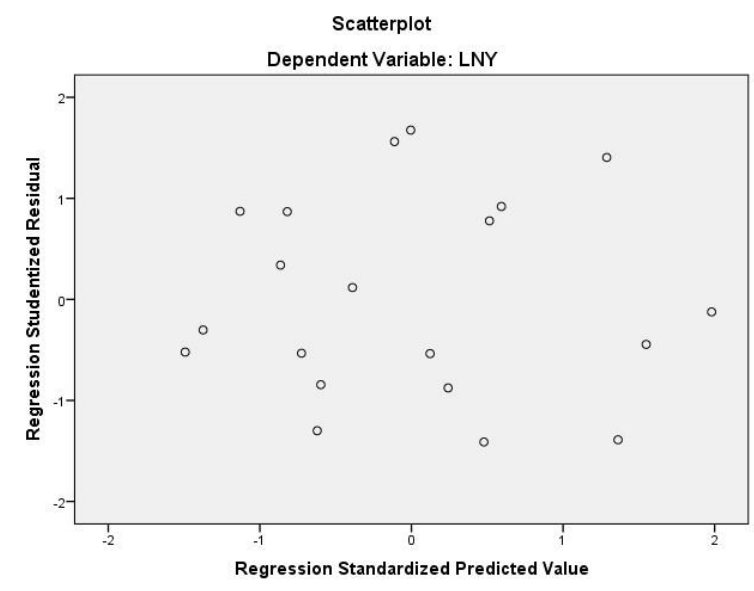

Sumber: Output SPSS, data yang diolah (2018) Gambar 4.1. Hasil Uji Heterokedastisitas

Dari hasil grafik scatterplot terlihat bahwa adanya titik-titik menyebar membentuk pola yang tidak jelas atau titik-titik tidak membentuk pola tertentu serta penyebaran titik- titik tersebut 
berada diatas dan dibawah angka 0 dan sumbu Y. Dengan demikian dapat disimpulkan bahwa model persamaan regresi tidak terjadi gejala heteroskedastisitas. Sehingga model regresi layak dipakai untuk memprediksi perencanaan pajak dan insesntif non pajak (earnings pressure, earnings bath, leverage dan ukuran perusahaan) sebagai variabel independennya.

\section{Uji Hipotesis}

Analisis Regresi Linier Berganda

Analisis regresi linier berganda digunakan untuk menguji secara simultan pengaruh variabel independen (X) terhadap variabel dependen (Y). (Sugiyono, 2014:277). Hasil dari analisis regresi linier berganda ini dapat dilihat pada tabel berikut ini :

Tabel 4.5

Analisis Regresi Linier Berganda

\begin{tabular}{|ll|ll|l|}
\hline & \multicolumn{2}{|l|}{ Unstandardized Coefficients } & Standardized \\
Coefficients
\end{tabular}

Sumber: Output SPSS, data yang diolah (2018)

Berdasarkan hasil analisis regresi berganda diperoleh persamaan sebagai berikut : $\mathrm{Y}=$ $2,555+0,055 \mathrm{X} 1+2,815 \mathrm{X} 2 \mathrm{a}-$ $0,084 \mathrm{X} 2 \mathrm{~b}-0,326 \mathrm{X} 2 \mathrm{c}+0,437 \mathrm{X} 2 \mathrm{~d}+$ $\varepsilon$

Tabel 4.5 menunjukkan prediksi masing-masing variabel. Dari persamaan regresi berganda diatas dapat diambil kesimpulan sebagai berikut :

Konstanta sebesar $\quad-0,2555$ menyatakan jika tidak ada perencanaan pajak (X1), earnings pressure (X2a), leveraga (X2b), earnings bath (X2c) dan ukuran perusahaan (X2d), maka manajemen laba (Y) nilainya negatif yaitu $-0,2555$.

Koefisien regresi variabel perencanaan pajak (X1) sebesar 0,055 dengan arah koefisien positif. Artinya jika variabel perencanaan pajak ditingkatkan sedangkan variabel lain tetap, maka akan meningkatan manajemen laba sebesar 0,055 satuan.

Koefisien regresi variabel earnings pressure (X2a) sebesar 2,815 dengan arah koefisien positif. Artinya jika variabel 
earnings pressure ditingkatkan sedangkan variabel lain tetap, maka akan meningkatan manajemen laba sebesar 2,815 satuan.

Koefisien regresi variabel leverage (X2b) sebesar -0,084 dengan arah koefisien negatif.

Artinya jika variabel leverage terjadi penurunan sedangkan variabel lain tetap, maka akan menurunkan manajemen laba sebesar -0,084 satuan.

Koefisien regresi variabel earnings bath (X2c) sebesar 0,326 dengan arah koefisien negatif. Artinya jika variabel earnings bath terjadi penurunan sedangkan variabel lain tetap, maka akan menurunkan manajemen laba sebesar $-0,326$ satuan.

Koefisien regresi variabel ukuran perusahaan (X2d) sebesar 0,437 dengan arah koefisien positif. Artinya jika variabel ukuran perusahaan ditingkatkan sedangkan variabel lain tetap, maka akan menyebabkan peningkatan manajemen laba sebesar 0,437 satuan.

\section{Koefisien Determinas (AdjustedR2)}

Koefisien determinasi pada hakekatnya mengukur seberapa besar kemampuan persamaan model dalam menerangkan variasi yang terdapat pada variabel dependen. Nilai $\mathrm{R}^{2}$ terletak antara 0 sampai $1\left(0 \leq \mathrm{R}^{2} \leq\right.$ 1). Koefisien determinasi dapat dihitung untuk mengetahui pengaruh variabel independen terhadap variabel dependen. Jika proses mendapatkan nilai $\mathrm{R}^{2}$ yang tinggi adalah baik, tetapi jika nilai $\mathrm{R}^{2}$ rendah bukan berarti model regresi jelek (Ghozali, 2016:95). Hasil koefisien determinasi dapat dilihat di tabel berikut :

\section{Tabel 4.6}

Uji Koefisien Determinasi (R2)

\begin{tabular}{|l|l|l|l|l|l|}
\hline & R & $\begin{array}{l}\text { R } \\
\text { Square }\end{array}$ & $\begin{array}{l}\text { Adjusted } \\
\text { R Square }\end{array}$ & $\begin{array}{l}\text { Std. Error } \\
\text { of the } \\
\text { Estimate }\end{array}$ & $\begin{array}{l}\text { Durbin- } \\
\text { Watson }\end{array}$ \\
\hline $\begin{array}{l}1 \\
\text { Model }\end{array}$ &, $612 \mathrm{a}$ &, 375 &, 151 & 2,04399 & 2,056 \\
\hline
\end{tabular}

a. Predictors: (Constant), LAGX2D, LAGX2B,

LAGX1, LAGX2A, LAGX2C

b. Dependent Variable: LNY

Sumber: Output SPSS, data yang diolah (2018)

Berdasarkan hasil pada tabel diatas dapat dilihat nilai R Square sebesar 0,151 yang berarti variasi variabel dependen (manajemen laba) yang dapat dijelaskan oleh variabel independen (perencanaan pajak, earnings pressure, leverage, earnings bath, dan ukuran perusahaan). sedangkan sisanya $84,9 \%$ dijelaskan oleh variabel lain diluar model penelitian ini.

Uji Signifikansi Simultan (Uji

Statistik F)

Uji $F$ pada dasarnya menunjukkan apakah semua variabel independen atau bebas dalam model terdapat pengaruh terhadap variabel dependen atau terikat secara bersama-sama. Untuk dapat mengetahui apakah variabel independen mempengaruhi secara bersama-sama variabel dependen maka digunakan tingkat signifikan sebesar 0,05 (Ghozali, 2016:96). Adapun kriteria diterima atau ditolaknya hipotesis adalah sebagai berikut :

Hasil Uji F, dapat dilihat dalam tabel berikut : 
Tabel 4.11

Uji Signifikansi Simultan (F-Test)

ANOVA $^{\mathrm{a}}$

\begin{tabular}{|ll|l|l}
\hline Model & & Sum of Squares & Df \\
& Regression & 4,697 & 5 \\
& Residual &, 215 & 14 \\
& Total & 4,912 & $\mid 19$
\end{tabular}

a. Dependent Variable: LNY

b. Predictors: (Constant), LAGX1, LAGX2a, LAGX2b, LAGX2c, LAGX2d

Sumber: Output SPSS, data yang diolah (2018)

Berdasarkan hasil uji simultan (F-test) diatas dapat disimpulkan bahwa nilai signifikansi 0,000 lebih kecil dari $0,05(0,000<0,05)$. Hal ini menunjukkan bahwa variabel perencanaan pajak, earnings pressure, leverage, earnings bath dan ukuran perusahaan secara bersamasama (simultan) berpengaruh signifikan terhadap manajemen laba, maka hipotesis diterima.

Uji Signifikan Parameter ( Uji Statistik t)

\begin{tabular}{l|l|l} 
Mean Square & F & Sig. \\
, 939 & 61,167 &, $000^{\mathrm{b}}$ \\
$\mid, 015$ & & $\mid$
\end{tabular}

$$
\mid
$$


secara parsial berpengaruh positif sebesar 2,815 dan signifikan sebesar 0,000 terhadap manajemen laba pada perusahaan manufaktur sub sektor otomotif dan komponen yang terdaftar di Bursa Efek Indonesia.

Leverage (X2b)

Dari hasil perhitungan uji $t$ menggunakan SPSS Versi 23, nilai koefisien regresi sebesar 0,084 dengan tingkat signifikansi $0,436>0,05$, maka hipotesis ditolak. Sehingga dapat disimpulkan bahwa leverage secara parsial berpengaruh negatif sebesar -0,084 dan tidak signifikan sebesar 0,436 terhadap manajemen laba pada perusahaan manufaktur sub sektor otomotif dan komponen yang terdaftar di Bursa Efek Indonesia.

Earnings Bath (X2c)

,326 dengan tingkat signifikansi $0,146>0,05$, maka hipotesis ditolak. Sehingga dapat disimpulkan bahwa earnings bath secara parsial berpengaruh negatif sebesar $-0,326$ dan tidak signifikan sebesar 0,146 terhadap manajemen laba pada perusahaan manufaktur sub sektor otomotif dan komponen yang terdaftar di Bursa Efek Indonesia.

Ukuran Perusahaan (X2d)

Dari hasil perhitungan uji $t$ menggunakan SPSS Versi 23, nilai koefisien regresi sebesar 0,437 dengan tingkat signifikansi $0,049<0,05$, maka hipotesis diterima. Sehingga dapat disimpulkan bahwa ukuran perusahaan secara parsial berpengaruh positif signifikan terhadap manajemen laba pada perusahaan manufaktur sub sektor otomotif dan komponen yang terdaftar di Bursa Efek Indonesia.

\section{KESIMPULAN DAN SARAN}

Kesimpulan

Berdasarkan analisis dan pembahasan yang telah dilakukan dalam penelitian ini dapat disimpulkan bahwa:

Perencanaan pajak dan insentif non pajak secara simultan berpengaruh signifikan terhadap manajemen laba.

Perencanaan pajak secara parsial berpengaruh signifikan terhadap manajemen laba.

Earnings pressure secara parsial berpengaruh signifikan terhadap manajemen laba.

Leverage secara parsial tidak berpengaruh terhadap manajemen laba.

Earnings bath secara parsial tidak berpengaruh terhadap manajemen.

Ukuran perusahaan secara parsial berpengaruh signifikan terhadap manajemen laba.

\section{Saran}

Penelitian lanjutan menjadi suatu hal penting dalam rangka mendukung perkembangan manajemen laba perusahaan di Indonesia. Berdasarkan hasil penelitian yang telah dilakukan ada beberapa saran yang dapat diajukan. Saran - saran yang dapat disampaikan adalah sebagai berikut :

Bagi perusahaan yang ingin melakukan investasi sebaiknya memperhatikan pemenuhan kewajiban jangka panjangnya dengan meningkatkan aktiva perusahaan, perusahaan dalam pertumbuhan penjualan hendaknya melihat faktor apa saja yang digunakan.

Bagi peneliti selanjutnya, periode tahun pengamatan sebaiknya diperpanjang dengan periode atau rentang waktu yang berbeda, serta memilih sampel perusahaan yang 
berbeda untuk mendapatkan hasil penelitian yang lebih baik.

Menambahkan variabel - variabel lain seperti beban beban pajak tangguhan, penerapapan good corporate governance dan lain-lain sehingga dapat meningkatkan kemampuan menjelaskan variabel dependen (manajemen laba) dan meningkatkan akurasi hasil penelitian yang diperoleh.

Untuk penelitian mengenai profitabilitas bisa memasukan variabel manajemen laba, karena berdasarkan hasil penelitian ini manajemen laba menjadi salah satu faktor yang mempengaruhi tingkat ekuitas perusahaan.

\section{DAFTAR PUSTAKA}

Aditama, F. d. (2014). Pengaruh Perencanaan Pajak Terhadap Manajemen Laba Pada Perusahaan Nonmanufaktur Yang Terdaftar di Bursa Efek Indonesia. MODUS, Vol. 26, No.1.

Astutik, R. E. (2016). Pengaruh Perencanaan Pajak Dan Beban Pajak Tangguhan Terhadap Manajemen Laba. Jurnal Ilmu dan Riset Ekonomi Vol. 5, No. 3.

Budiman, S. R. (2013). Pengaruh Insentif Pajak dan Insentif Non PajakTerhadap Manajemen Laba (Studi Empiris pada Perusahaan Manufaktur yang Terdaftar di BEI Indonesia Tahun 2009-2013). Jurnal Akuntansi.

Ghozali, I. (2016). Aplikasi Analisis Multivariete dengan Program IBM SPSS 23. Semarang: Badan Penerbit Universitas Diponegoro.

Hamijaya, M. (2015). Pengaruh Insentif Pajak dan Insentif Non Pajak Terhadap Manajemen Laba Saat Terjadi Penurunan Tarif Pajak Penghasilan Badan Pada Perusahaan Manufaktur yang Terdaftar di BEI. Jurnal Akuntansi dan Bisnis Vol. 14, No. 27.

Harnanto. (2013). Perencanaan Pajak. Yogyakarta: BPFE-Yogyakarta. Mardiasmo. (2016). Perpajakan. Yogyakarta: Andi.

Munawir. 2016. Analisa Laporan Keuangan. Yogyakarta. Liberty

Oktavia, dan Subagyo (2010). Manajemen Laba Atas Respon Perubahan Tarif Pajak Penghasilan Badan di

Indonesia. SNA 13, Purwokerto 2010.

Philips, John, Morton Pincus dan Sonja Olhoft Rego. Earnings Management : New Evidence Based on Deferred Tax Expense. The Accounting Review, Vol. 27.

Sekaran, U. (2006). Metodologi Penelitian untuk Bisnis. Jakarta: Salemba Empat. Sekaran, U. (2011). Metodologi Penelitian untuk Bisnis. Jakarta: Salemba Empat.

Slamet, A. d. (2012). Respon Perubahan Tarif Pajak Penghasilan, Insentif Pajak dan Non Insentif Pajak Terhadap Manajemen Laba. Jurnal Auntansi, Bisnis dan Manajemen, Vol.1, No.1 . Sugiyono. (2014). Metode Penelitian Bisnis. Bandung: CV Alfabeta. 
Sulistyanto, S. (2014). Manajemen Laba Teori dan Model Empiris. Jakarta: PT Grasindo.

Sulistyo, Wahyu Adhy Noor. 2010. Analisis faktor-faktor yang berpengaruh terhadap ketepatan penyampaian laporan keuangan pada perusahaan yang listing di BEI periode 2006-2008. Skripsi. Sarjana Fakultas Ekonomi Universitas Diponegoro. Semarang

Tunggal, A. W. (2010). Ikhtisar Teori dan Tanya-Jawab Audit Internal. Jakarta: Harvarindo.

Widyawanti. (2014). Analisis Pengaruh Perubahan Tarif Pajak Penghasilan Sesuai UU No.36 Tahun 2008 Terhadap Praktik Earnings Management Sebagai Motivasi Penghematan PPh Badan. Skripsi, Unsoed.

Wild, John J., K.R. Subramanyam and Robert F. Hasley. (2004). Financial Statements Analysis, 8th ed. Boston: Mc. Graw-Hill.

Yenisa, Dewi Utami. 2017. Faktor-Faktor mempengaruhi ketepatan waktu pelaporan keuangan pada perusahaan sub sector bank di Bursa Efek Indonesia. Jurnal Akuntansi Dewantara. Vol.1: No.1

www.idx.co.id www.sahamok.co.id 